\title{
The heterodox notion of structural crisis
}

\author{
Robert Guttmann \\ Hofstra University, New York, USA
}

\begin{abstract}
Long waves of economic activity, also known as 'Kondratiev cycles,' have been known to exist for nearly a century without having ever been given a proper theoretical context. In this paper we try to identify various contributions to shed light on this phenomenon, notably Schumpeter's notion of technological bursts and Minsky's notion of a super-cycle where 'stability breeds instability' to the point of systemic crisis. A more comprehensive and methodologically innovative approach to the periodization of capitalism is the French Régulation School. This heterodox approach has reframed the story of long waves in terms of periodspecific 'accumulation regimes' and 'modes of (self-)regulation.' Here systemic crises, like the ones we experienced in 1873-1879, 1929-1939, 1973-1982 or 2007-2011, play the role of regime-transforming adjustments in the institutional make-up of the wage relation, forms of competition, state intervention, and money and banking, as well as international context. We apply the Regulationist approach to finance-led capitalism, the latest longwave accumulation regime emerging around 1982 to find itself confronted with its own systemic crisis starting in 2007. How will that crisis, one of the most profound structural crises to date, change our economic system?
\end{abstract}

Keywords: central banking, financial institutions, crisis

JEL codes: $B 2, B 26, B 5, E 3, E 5, G 2$

\section{INTRODUCTION}

We are currently going through one of these once-in-a-lifetime economic crises which happens to be far more serious and enduring than your typical business-cycle downturn that we experience every 5 to 10 years for a few quarters at most. No, the current crisis already appropriately termed the Great Recession - is far different than, say, the last couple of US recessions in 1990-1991 and 2000-2001. What we have here instead can better be characterized as a structural crisis. Such a crisis, which we had experienced earlier from 1873 to 1879,1929 to 1939 , or 1973 to 1982 , typically lasts for several years, engulfs much of the globe, and does not end unless fundamental change in policy or in institutional make-up has been put in place to resolve the imbalances underlying that crisis. In other words, this type of crisis drags on until met by appropriate change.

To the extent that such a phenomenon defies the mainstream economist's belief in selfadjusting markets and balanced growth paths, it lies outside the purview of orthodox economic thinking. That itself makes structural crisis a worthwhile object of analysis. But the purpose of its investigation needs to go further than that. Each time capitalism has encountered such a storm, the system has changed quite fundamentally - as if taking a leap forward. The purpose of this paper is to investigate how we ended up once again in such a structural crisis and what we face as we are trying to put it behind us. 


\section{STRUCTURAL CRISIS FACTORS}

\subsection{Long waves}

Given that structural crisis seems a recurrent phenomenon, albeit one spaced decades apart, we may place it within a long-wave dynamic defining the rhythms of capitalist evolution over the longer run. The existence of such long waves was first postulated by the Soviet economist Nikolai Kondratiev (1925 [1984]; 1926 [1936]), who identified distinct phases of rapid growth followed by sustained periods of slower growth over 50- to 60-year periods. Those were later named 'Kondratieff waves' and given a technological interpretation by Joseph Schumpeter (1939). This Austrian economist, in his seminal study of different types of cycles, surmised the presence of bursts of innovation which move in clusters across a growing number of sectors to boost overall growth. Sustained slowdowns occur when these technological bursts exhaust themselves. ${ }^{1}$

\subsection{Technological innovation}

If we were to take seriously the idea of technological revolutions as the driving force for long waves, we could periodize those in terms of the Industrial Revolution (1787-1843), the age of the railroad and steam engine (1842-1897), the age of steel, electricity, and internal combustion (1897-1939), war and postwar boom period rooted in suburbia and thus anchored around housing and cars (1939-1982), and the post-industrial era of the 'Information Revolution' centered on the internet (1982-?). ${ }^{2}$ The end points of these waves represent the troughs after periods of sustained stagnation, with the turning-point peaks occurring respectively in 1819, 1873, 1929, 1969, and 2007. A decade or two of slow growth and rapidly recurrent downturns later, at the troughs then (that is, 1842, 1897, 1939, 1982), the lowering of prices and production capacities would typically have ripened enough for a new technological revolution to take hold and push the economy onto a faster growth path for the next couple of decades.

While there may be a lot to the notion of technology-driven long waves (see, for instance, the path-breaking work of German innovation expert Gerhard Mensch (1979)), the excellent survey by Gerald Silverberg (2003) makes clear at the same time how difficult it is to trace such long-run trends empirically or model them conceptually. It is simply beyond normal quantitative-statistical methods to grasp fully the key dimensions of technological revolutions and their spread through an economy's matrix of industries. Still, we know one reasonably measurable thing for sure: long-wave upswings have a tendency to turn into booms as the pace of productivity-gains accelerates. This pattern may well indicate rapid technological change leading to more automated production methods and/or giving rise to new fast-growth industries - both sources of improved factor productivity.

1. In this context Schumpeter (1942) famously coined the phrase creative destruction to describe the destructive impact of transformative technologies in rendering prevailing industrial structures, older production methods, and established institutions obsolete. While the destructive impact of technological revolution occurs typically in its early boom phases, it can linger on beyond the "creative' phase of vibrancy and contribute to stagnation - to the point where Schumpeter saw this contradictory force as potentially undermining the viability of capitalism itself.

2. See the Wikipedia entry on the 'Kondratiev wave' for this periodization (http://en.wikipedia. org/wiki/Kondratiev_wave). 


\subsection{Falling profitability}

What the protagonists of the Kondratiev wave have failed to spell out clearly is how and why the economy moves from an upswing phase to a downswing phase. Their original focus on long-term price trends and patterns of technological change managed to distinguish clearly periods of boom and stagnation, but did not say much about the transition from one to the other. If, however, we can discern a regular pattern of productivity spurts near the cyclical peak, then this points to a possible build-up of overproduction conditions, especially to the extent that we can observe productivity gains outpacing wage growth. In this situation aggregate supply tends to grow faster than aggregate demand. The ensuing imbalance can indeed trigger a sort of crisis when a build-up of unsold inventories in the face of slowing sales forces production cuts and lay-offs.

Such an intrinsic sequence of boom, overproduction, crisis, and retrenchment is at the core of Marxist analyses, starting with the master himself in his magnum opus Das Kapital (Karl Marx, 1867 [1992]; 1894 [1959]). Throughout his huge body of work Marx analysed capitalism as a system whose unfettered forces of production clash inevitably with its constraining relations of production. Competition drives firms to increasingly automated and capital-intensive production methods, as a prerequisite for the productivity gains needed to stay competitive. ${ }^{3}$ This drive eventually undermines itself by lowering the profit rate - a trend Marx saw as more or less inevitable to the degree that automation shrank the source of profit, the unpaid labor time extracted from the work-force ('surplus value') relative to the ever-growing capital base, so that the numerator in the profit-rate ratio would not keep up with the denominator. One can think of this contradiction also in under-consumptionist terms, especially when focusing on the dual nature of the wage. On the one hand, the wage is a dominant cost of production; on the other hand, it is also the largest source of aggregate demand. Each capitalist wants the wages of his workers to be as low as possible while at the same time wishing the wages of all the other workers to be as high as possible (as consumer spending). Either way, it is fair to conclude that the system breeds a tendency towards declining profit rates amidst rising excess capacities. Here again we should note a systematic pattern of sharply declining profitability near the long-wave peak, as happened in the United States for instance in the late 1920s, in the late 1960s, and then again in the mid 2000s.

\subsection{Financial instability}

While a sustained fall in profit rates is a necessary prerequisite for crisis, it may not be a sufficient one. As a matter of fact, Marx did not view falling profit rates as a direct and automatic trigger of crisis. ${ }^{4}$ At the same time Marx insisted, especially in chapter 14 of Volume III of Capital (1894 [1959]), that we also needed to take account of counter-tendencies working against this 'law of the tendency of the rate of profit to fall' aimed at restoring profitability. These include increasing the rate of exploitation of workers, decreasing the wage, cheapening the plant and machinery used in production ('constant capital'), relative overpopulation, and foreign trade. Those forces may operate concurrently with the pressures driving the profit rate down, thereby slowing

3. Productivity fosters competitiveness to the extent that it lowers unit costs. Once in such a position, firms can then charge less on their products (and still maintain their profit margin) or obtain higher profit margins (at the same sales price).

4. Nor did some of his most influential followers, such as Ernest Mandel $(1970 ; 1980)$ or Gerard Duménil and Dominique Lévy $(1993 ; 2002)$. 
that trend. For instance, technological change can yield much cheaper capital goods, thus lowering the denominator in the profit-rate ratio. In recent years emerging-market economies, like China's, have achieved sustainably rapid expansion despite low wages (and consequently small consumption share in GDP) through export-led growth, confirming the power of foreign trade in sustaining profitable expansion. But these countervailing tendencies are much more forceful in the course of economic crises. Under these conditions it is more likely for firms to squeeze more out of workers, lower wages in the context of mass unemployment (Marx's relative 'overpopulation'), cheapen capital goods, or push harder for exports. We can therefore surmise that falling profit-rates and countervailing tendencies reversing that trend occur sequentially, with the former leading to the latter via outbreaks of acute crisis conditions.

What moves overproduction conditions and declining profitability inevitably to the point of acute crisis are sudden outbreaks of financial instability. These occur typically near the cyclical peak, trigger a credit crunch, and thereby impose a recessionary adjustment of spending cutbacks, forced asset sales, and cash hoarding on overextended borrowers. We thus have a credit cycle (of rapidly growing debt during the upswing phase and deleveraging during the downturn phase) superimposed on our business cycle of production and employment, and the two are actively intertwined in mutually reinforcing fashion. The point when boom turns to crisis is thus typically associated with a sudden incidence of financial instability - a spectacular failure of a key firm, a run on banks, a stock-market crash - which reveals clearly a hitherto hidden degree of overextension of debts, prices, and income-generation commitments. Such an unmistakable signal causes fears to explode, as a result of which creditors of all stripes cut back. To the extent that such a generalized credit crunch deprives many debtors suddenly of essential funding support, those too have to cut back spending, possibly even sell off assets (into already declining markets), to generate the cash they can no longer simply borrow.

Already the Austrian School has given us a good sense how the 'real' economy of production and exchange might interact with the credit system in cyclical fashion. Its principal protagonists, notably Ludwig Mises (1912 [1953]) and Friedrich Hayek (1933 [1975]; 1935 [1967]), saw the business cycle as the result of a credit-driven boom during which excessively low interest rates induce businesses to over-expand their investment spending to ultimately unsustainable levels. The subsequent downturn then appears as a necessary adjustment process, which eliminates the misallocated malinvestment and corrects misleading price signals from an interest rate kept too low for too long by an irresponsible central bank. Even though vehemently attacked from both left and right, Austrian business cycle theory provides an interesting integration of endogenous money creation, interest rates, investment spending, and (re-)allocation effects between consumption goods and capital goods. ${ }^{5}$

An even better understanding of the role of financial instability at the cyclical peak can be gained from the work of certain post-Keynesian economists. The key driver in that approach is financial as well, specifically debt-financing of investment spending that is amply available and encouraged during the boom period only to be rendered much more restricted in the subsequent credit crunch. Hyman Minsky (1982; 1986; 1992) put forward the financial-instability hypothesis according to which excessive levels of

5. That sequence, which recurrently yields striking but ultimately unsustainable periods of boom conditions, has allowed several 'Austrians,' including libertarian presidential candidate Ron Paul, to warn of 'impending doom' at the height of the housing bubble in the mid 2000s and so appear to have been remarkably prescient in hindsight. 
indebtedness, motivated by boom-induced optimism about future income growth potential, leave debtors vulnerable as their debt-servicing charges rise in relative importance. Initially a majority of borrowers may still find themselves in the relatively secure position of hedge finance where they have enough income to pay off interest and principal. But as booming conditions induce more borrowing, a growing number of debtors will find themselves in the more precarious position of speculative finance where they can still cover interest payments on their debt but are no longer able to pay off the principal in full. Finally, excessively leveraged debtors may well end up in the far more desperate position of Ponzi finance where they can only service their old debt by taking on new debt. When many debtors have reached this stage of Ponzi finance, then you have the kind of financial fragility present in the economy that may lead to a full-blown credit crunch - a situation rendered more likely near the cyclical peak, when rising debt-servicing charges coincide with declining profit rates and consequently intensifying cash-flow gaps. It is at that point that we typically end up with a Minsky moment, signaling the acute outbreak of a financial crisis strong enough to impose a recessionary adjustment on overextended debtors and their worried lenders.

\subsection{Systemic crises}

This financial-instability hypothesis applies essentially to the shorter-term ups and downs of the economy known as the business cycle. Minsky (1980) himself regarded recurrent financial instability as part of such a business-cycle dynamic when he linked it to the cyclical profit-investment interaction of the kind espoused by Polish economist Michal Kalecki $(1935 ; 1937 ; 1942)$. Early on in his career, however, Minsky (1964) had taken a longer, supra-cyclical view of financial fragility, which he saw as building up gradually over several cycles in cumulative fashion. It is there that we encounter for the first time Minsky's insistence that 'stability breeds its own instability,' as economic actors, convinced by the success of their earlier bets that they can afford to take on more debt for further expansion of spending, engage in increasingly risky financing positions. During the boom phase of a long-wave upswing, when downturns are quite rare, shallow, and short-lived, we will not only see more and more risk being taken with each successive cycle by increasingly euphoric economic actors, but also a supra-cyclical build-up of leverage in the absence of strong-enough recessions that would normally have corrected such excess by forcing debt levels down. This insight gives Kondratieff waves a whole new, primarily financial dimension. ${ }^{6}$

If we wish to integrate this decisive insight of a supra-cyclical build-up of financial fragility into our analysis of long waves, we have to recognize that their upswing phases typically involve gradually increasing debt levels and servicing charges that leave heavily indebted actors vulnerable to any decline in their income or asset values. When such a squeeze scenario finally arrives, some debtors will fail spectacularly and so trigger a financial crisis that spreads rapidly due to the prevalent financial fragility and so morphs soon into a systemic crisis. In their data-driven study of eight centuries of financial instability, spanning over 60 countries and pointing to a breathtaking variety of financial crises ranging from banking collapses to hyperinflation to government debt defaults to currency collapses and beyond, Carmen Reinhardt and Kenneth Rogoff

6. Tom Palley (2009) has characterized this notion of a supra-cyclical build-up of leverage, risk-taking, and fragility in terms of dangerously unsustainable financing positions as Minsky's 'Super-Cycle.' 
(2009) point to a recurrent pattern of amnesia, euphoria, and hubris which prompt economic actors to engage in excessive risk-taking and so expose themselves eventually to untenable levels of indebtedness to the point of self-destruction. These authors, besides showing a recurrent pattern of financial crises coming about in clusters, also demonstrate empirically in convincing fashion that excessive debt levels are associated with particularly deep systemic financial crises hitting the entire banking sector from which national economies find it difficult, if not impossible, to recover swiftly.

The great French economist Michel Aglietta (1996; 2001) has systematically explored the systemic risk underlying the processes leading to a full-blown financial crisis capable of significant negative macroeconomic effects. ${ }^{7}$ In such a 'systemic crisis,' the normal functioning of financial markets and institutions has broken down to disrupt much-needed credit supplies and thus imposes widespread spending cutbacks and asset sales by overextended debtors in desperate need for more cash as a matter of survival. Aglietta's work on systemic risk/crisis has the added advantage of identifying distinct types of financial crises - whether stock-market crash, capital flight out of a country and/or its currency, bank runs, payment-system blockages, or technological breakdowns (like the so-called 'flash crash' on 6 May 2010) - and then trace their respective contagion dynamics to the point of widespread paralysis.

Such work on the typology of systemic crises has been pushed even further by the important study of Robert Boyer, Mario Dehove, and Dominique Plihon (2004) in terms of combining empirical facts (for example, the pro-cyclical behavior of credit supplies and financial markets moving from euphoria to panic and back) with theoretical notions (for example, financial fragility). They conclude, based on empirical fact and historical lessons, that the big systemic crises capable of significantly disrupting economic activity on a broad scale are those that have hit the banking system sufficiently hard as to trigger a massive credit crunch. Boyer and his colleagues stressed in addition that major financial crises have typically also been linked to serious underlying macroeconomic imbalances whose debt-dependent accommodation could no longer be sustained beyond a certain point. The credit crunch is then the mechanism obliging a crisis-enforced rebalancing where other (price-based or policy-induced) adjustment mechanisms had failed to do the job. ${ }^{8}$

\section{REGULATION THEORY}

\subsection{Accumulation regimes and modes of regulation}

We should note that the aforementioned group of economists discussed in the last subsection on systemic crises - Aglietta, Boyer, Dehove, Plihon - belongs to a French

7. Aglietta's original contribution to the discussion of systemic risk offered a typology of systemic crises which may arise via stock-market crashes, banking runs, or payments-systems disruptions and then spread to endanger the entire process of credit supply (Michel Aglietta and Philippe Moutot 1993).

8. For more on different types of financial crises capturing the variety of systemic-risk sources, see the wonderful historical accounts of Charles Kindleberger (1978), the three generations of currency-crises models corresponding to the major episodes of international financial instability in the 1970s, the mid 1980s, and throughout much of the 1990s (Paul Krugman 1979; Maurice Obstfeld 1986; Roberto Chang and Andrés Velasco 2001; Craig Burnside, Martin Eichenbaum and Sergio Rebelo 2004), or the relatively complete and well-structured Wikipedia entry on 'financial crisis' (http://en.wikipedia.org/wiki/Financial_crisis). 
heterodox tradition in economics that has made an arguably crucial contribution to the analysis of structural crisis. This approach, known as théorie de la régulation ('Régulation Theory'), employs an institutionalist perspective to analyse the longterm evolution of the capitalist system in terms of consecutive regimes d'accumulation ('accumulation regimes') each of which is characterized by its own unique modus operandi of self-regulation - something the Régulationists have termed mode de régulation. ${ }^{9}$ An accumulation regime's specific mode of regulation comprises the interactional dynamic of any capitalist system's five institutional pillars:

1. forms of competition (that is, degree of concentration, price formation, competition among workers);

2. the monetary regime (that is, money forms, monetary policy, credit supplies);

3. state intervention (especially in the areas of economic and social policy);

4. the wage relation (including determinants of wages and employment, and organization of work); and

5. international economic relations determining a given country's insertion into the world economy via trade, cross-border capital flows, and exchange rates.

Looking in more detail at each of these institutional pillars and analysing systematically how they interacted with each other, the Régulationists ended up identifying four consecutive accumulation regimes over the last century and a half. ${ }^{10}$

1. The conclusion of the Industrial Revolution, around 1850 in much of Europe and the United States, was followed by what the Régulationists have termed a competitive accumulation regime which centered on relatively small producers and price-mediated competition. Growth relied heavily on expanding the capital stock and the labor force; that is, 'extensive' accumulation.

2. The competitive accumulation regime experienced gradual transformation through a distinct monopolization trend towards the end of the nineteenth century, reinforced by new production methods ('Taylorism') that greatly boosted productivity while allowing highly skilled workers and their closed-shop crafts unions to be replaced with semi- and unskilled workers. As productivity growth outpaced wage gains for much of the interwar period, a major overproduction crisis became inevitable: the Great Depression of the 1930s.

3. The postwar period gave rise to what Régulationists have characterized as the Fordist accumulation regime whose significant productivity gains were matched by regular wage increases so that the spread of mass production technology could be accompanied by the development of social norms of mass consumption anchored around home ownership and cars. That regime tumbled into a peculiar crisis dynamic known as stagflation in the late 1960s, from which we only emerged a decade and a half later amidst a conservative counter-revolution justifying rather extensive policy reforms.

4. Those reforms, led by Thatcher in the United Kingdom and Reagan in the United States, helped nourish a new finance-driven accumulation regime which the

9. The Régulationists emerged in the late 1970s, at the tail end of the previous structural crisis which took the unique form of stagflation. See, in this context especially, the founding texts of Michel Aglietta (1976 [1979]), Robert Boyer and Jacques Mistral (1978), Benjamin Coriat (1979), and Alain Lipietz (1979). See also the excellent summary of régulation theory's key concepts and arguments by Robert Boyer and Yves Saillard (1995 [2002]).

10. Robert Brenner and Mark Glick (1991) provide a usefully critical assessment of the Régulationists' four consecutive accumulation regimes and their respective transitions. 
Régulationists initially characterized as patrimonial capitalism before settling on the internationally more recognizable notion of finance-led capitalism. ${ }^{11}$ It is the excessively speculative, globally imbalanced, and inequality-enhancing nature of this new regime that produced the Great Recession of 2007-2009, a structural crisis from which we are only now beginning to emerge ever so haltingly.

Régulation Theory offers an innovative approach to periodize the evolution of capitalism in distinct stages, emphasizing the multi-faceted nature of the system by giving it a broad institutional context within which social relations, politics, demographics, technology, and social-psychological determinants of group behavior all take their proper place alongside the laws of economic change. With regard to the latter, Régulation Theory has demonstrated a welcome flexibility and ambition to connect the insights of key 'outside of the box' thinkers, be they Karl Marx, Thorstein Veblen, John Maynard Keynes, Joseph Schumpeter, Michal Kalecki, or Hyman Minsky, toward a systematic theory of capitalism's evolutionary tendencies. Herein, in this explicit effort at integrating different heterodox approaches to develop a coherent meta-theory of the system and its long-term growth dynamic, lies one of the great strengths of Régulation Theory. One could even argue that its historically bound accumulation regimes each correspond to a specific long wave: the 'competitive' regime from 1848 to 1896; the 'monopolistic' regime from1896 to 1945; the 'Fordist' regime from 1945 to 1982; and the 'finance-led' regime from 1982 to 20??. Even if the time periods concerned do not exactly match Kondratiev's own timetable for long waves (that is, 1789-1844, 1844-1896, 1896-1949, and 1949-2007), it is quite obvious that the Régulationists' notion of accumulation regimes represents an important effort to contextualize the idea of long waves both historically and institutionally. ${ }^{12}$

\subsection{Structural crises}

Bearing in mind this connection between accumulation regimes and long waves, the question arises of what happens during the transition from one regime to another. It is precisely here that Régulation Theory makes an indispensable contribution to our understanding of structural crisis. Régulationists stress that crises are an endogenous feature of our capitalist system. And here they make a crucial distinction between 'cyclical crises,' the downturns that are a normal part of the inherently cyclical growth dynamic by which the market mechanism balances aggregate demand and supply, and 'structural crisis,' indicating the inability of an accumulation regime to sustain itself amidst disintegration of its institutional pillars and malfunctioning of its mode of

11. See the original discussion of capitalisme patrimonial in Michel Aglietta and Antoine Rebérioux (2004 [2005]), who incidentally talk in the English edition of finance-driven capitalism. Robert Boyer (2000) refers to the new regime in terms of finance-led growth. The notion of finance-led capitalism has been framed in terms of constituting a new accumulation regime with its own distinct mode of regulation via rent-seeking financial markets and asset bubbles in Robert Guttmann (2008). European post-Keynesians sympathetic to the Régulation Theory, such as Engelbert Stockhammer (2008) or Eckhard Hein (2012), prefer the notion of finance-dominated capitalism. An excellent summary of the overlaps and differences between post-Keynesian theory and Régulation theory can be found in Mark Setterfield (2011).

12. For up-to-date calculations and graphs of Kondratiev waves, see the websites http://www. kondratieffwavecycle.com/kondratieff-wave/ and http://kondratieffwinter.com/blog/. 
regulation (Boyer 1990; 2004). In the latter situation, akin to what happened in 1929 or in 2008 , the system cannot avoid a downward spiral accompanied by institutional upheaval nor resume sustained expansion unless substantially reformed. ${ }^{13}$

\section{FINANCE-LED CAPITALISM}

\subsection{Deregulation of money and banking}

The historical-institutional orientation of Régulation Theory permits us to trace the current structural crisis all the way back to the stagflation crisis of the 1970s which ended with a brutal disinflation process in 1979-1982 engineered by a determined US central bank deregulating (hitherto tightly controlled) interest rates and employing selective credit controls. These measures, imposed by an acute crisis of confidence in the viability of the US dollar as world money that had grown steadily ever since the collapse of the dollar-centered Bretton Woods system of international monetary relations in August 1971, formed part of a broader deregulation effort pertaining to the financial sector. In short order, US regulators deregulated the prices of money (exchange rates in March 1973, interest rates in October 1979), widened the varieties of private-bank money (from the appearance of interest-bearing checking accounts and money-market funds in 1975 to the St Germain-Garn Depository Institutions Act of 1982), permitted derivatives to hedge against financial volatility, dismantled barriers between different financial institutions, and so encouraged securities traded in financial markets to crowd out bank loans as the primary form of credit. This financialderegulation effort was given a global dimension as the United States, not least via its control of the key multilateral institutions (the International Monetary Fund, the World Bank), pushed other countries to remove capital and exchange controls, adopt more flexible exchange rates, make their central banks politically independent, and put their fiscal houses in order under the rigors of the global sovereign-bond market.

There is no question that this radical dismantling of nationally administered credit systems in the 1980s was motivated by politics. We were, after all, in the midst of a conservative counter-revolution, launched in 1979 by Margaret Thatcher in Britain and in 1980 by Ronald Reagan in the United States. It helps in this context also that London and New York were the two financial centers of the world, extending their global reach beyond money to ideology. Moreover, just as the stagflation dynamic had benefitted debtors at the expense of creditors (via negative real interest rates, paying back principal with devalued dollars, and purely nominal 'paper' profits), so the combination of disinflation and deregulation was a response by the creditors (and their investor clients) pushing hard for restoration of their income-creation capacity.

But the deregulation of money and banking also had a deeper, structural dimension. It was part of a regulatory dialectic characterizing the monetary regime (see Edward Kane 1981) whereby banks respond to new regulatory constraints with regulationevading innovations, then use their newly found freedoms to drive the credit system to excess, and so create the conditions for major financial instability in the wake of which governments introduce new regulatory constraints - only for the whole process to resume again. And let us also not forget that all the key steps in this decade-long

13. In this regard, Bob Jessop (2001) provides probably the most complete collection of the Régulationists' arguments on crisis in capitalism. 
financial deregulation process occurred in direct response to acute crisis conditions necessitating a major change with regard to that specific aspect of the monetary regime in question - from the collapse of Bretton Woods amidst a sustained global flight out of the US dollar in 1971 all the way to the reorganization of banking in 1989.

\subsection{Financialization}

Be that as it may, the deregulation of finance combined with its computerization and its globalization to transform our credit system profoundly. ${ }^{14}$ At the same time, the Reagan Revolution also favored the rise of an investor class by sharply lowering the marginal tax rates on the wealthiest households, more than halving the taxation of capital gains (to far lower levels than the taxation of other forms of capital income), promoting tax-sheltered savings plans, and encouraging corporate managers to be paid much more in the form of stock options. These investors merged with the newly liberated bankers to form a very powerful coalition of financial-market participants - what Randall Wray $(2009 ; 2011)$ has characterized in Minskyan terms as money manager capitalism - seeking to appropriate a growing share of the aggregate income pie in the form of capital gains, dividends, interest income, fees, and commissions.

Underlying this redistribution of income towards financial investors and institutions, a trend which in turn reinforced industrial firms' efforts to depress wages shares in order to defend their profit shares, was a powerful process we have characterized as financialization. ${ }^{15}$ At the center of this process is the principle of shareholder value maximization which has come at the expense of other stakeholders (workers, consumers, local communities) and crowded out all other aspects of corporate governance. The diktat of shareholder value has been reinforced by several reinforcing changes: stock options incentivizing managers as shareholders; the growing importance of institutional investors who judge firms solely on the basis of current quarterly earnings; and firms relying increasingly on mergers and acquisitions as their primary mode of expansion. In the wake of these trends, corporations have dramatically expanded their financial assets while investing less in productive assets.

If we look at financialization as the process of dramatically expanding the role of finance in our economy, that trend could be seen on both sides of the balance sheet. Economic actors across the board came to operate with steadily rising levels of leverage to boost financial liabilities while also building up their financial assets in the chase for rapid capital gains and other forms of financial income. The two, of course, go literally hand in hand as assets serve as collateral for liabilities.

The fastest growth, however, in this financialization process accrued to the financial institutions themselves, whether commercial banks or various types of funds or investment banks. They have doubled their levels of leverage over the last couple of decades, using massive amounts of borrowed funds to expand their portfolios rapidly. Built into this phenomenal expansion of the finance sector was also the growing interconnectedness of financial transactions and instruments into tightly intertwined webs of contractual promises and cash-flow commitments. Many of the most important recent innovations in our credit system, such as asset-backed securities, collateralized debt

14. See Robert Guttmann (1997) for a more complete discussion of finance's transformation by means of its deregulation, globalization, and computerization.

15. Interesting discussions of this financialization trend can be found in Greta Krippner (2005), Gerald Epstein (2006), and Ozgur Orhangazi (2008). 
obligations, futures and options, and credit-default swaps, have ended up adding new layers of financial arrangements and contracts that are tied to each other. These layers were able to grow exponentially by taking the form of public-exchange and over-thecounter markets attracting lots of capital from across the globe channeled through a growing array of (pension, mutual, hedge, private-equity, exchange-traded, and sovereign-wealth) funds.

\subsection{Financial globalization}

The incredible expansion of finance embodied in this financialization trend has been a worldwide phenomenon thanks to relentless financial globalization - with banks becoming truly transnational actors, funds diversifying their portfolios globally, previously national securities markets hooking up with each other across borders, and the vast foreign-exchange market (with a daily transaction volume approaching $\$ 4$ trillion) providing a highly efficient platform for moving large funds in and out of markets, countries, and currencies at the speed of light. Such financial globalization has been the spearhead of a broader internationalization process which encompasses far higher levels of trade (notably of services in cyberspace), the formation of global supply chains through massive 'offshoring' or 'outsourcing,' the concomitant explosion of intra-firm trade in components and parts among subsidiaries of the same production network, cross-border alliances and mergers of firms as more and more industries are turning into global oligopolies, and large migrations of people to where more lucrative opportunities may arise.

Financial globalization has drawn a growing number of previously rather closed countries into the orbit of capitalism. Very helpful in this context have been two shadow-banking systems, each set up on a global scale to operate beyond the reach of national authorities and hence free of regulatory constraints. The first, emerging as a force to reckon with in the 1960s, are the so-called Eurocurrency markets. This global banking network comprises a couple of hundred super-large financial institutions that are connected to each other through computerized payments systems (SWIFT, CHIPS) as well as a huge inter-bank market for short-term funds. ${ }^{16}$ The other shadow-banking network arose in the 1980s when US pension funds and mutual funds undertook global diversification of portfolios and so ended up investing heavily abroad, boosting in the process the credit systems and macroeconomic performance of European, Latin American, and East Asian economies. This wave of capital transfers benefited from the global removal of capital and exchange controls opening up hitherto closed economies. The US funds also found those countries more attractive after structural-adjustment reforms had finally begun to bear fruit and the policy mix there had improved. The stage was set for turning many - perhaps 60 to 70 - countries into emerging markets, including the countries of the former Soviet Union and its 'zone of influence' after that empire's collapse in 1991.

16. The SWIFT network (for Society of Worldwide International Financial Telecommunications) regulates the information and data flows between banks transferring funds to each other. CHIPS (for Clearing House Interbank Payments System) settles currency exchange transactions between banks. The inter-bank market is a network of banks providing short-term funds to each other, mostly in the form of repurchasing agreements. For a good analysis of the structure, operational capacity, and regulatory challenges defining the Eurocurrency market see Edward Frydl (1979; 1982). 


\subsection{Emerging markets and currency crises}

During the 1970s the transnational banks comprising the Eurocurrency markets organized the huge recycling of OPEC's 'petro-dollars.' This set off a major global crisis in the early 1980s when dozens of heavily indebted countries suddenly found themselves squeezed between sharply rising debt-servicing costs and precipitously falling export earnings - a double whammy from the Fed-induced disinflation mentioned above (in Section 4.1). While that so-called $L D C$ debt crisis led to difficult adjustment programs, institutional reforms, and debt restructurings between 1982 and 1989 under the auspices of a tough IMF, it also ended up inserting many of the countries affected, especially those in Latin America (for example, Argentina, Brazil, Mexico), much more tightly into the world economy as they were obliged to open up their economies while at the same time sharply devaluing their currencies.

The second shadow-banking system mentioned above (in Section 4.3), built around a network of globally diversifying US pension and mutual funds, created yet another major worldwide financial crisis 15 years later. In July 1997, following a botched devaluation of the Thai baht, panicky US funds rushed out of East Asian economies (from Thailand to Korea) after realizing that those economies had begun to overheat and become prone to local asset bubbles after several years of credit-fueled growth. In contrast to the LDC debt crisis of the previous decade, this currency crisis unfolded with much greater speed and contagion potential. Funds owning securities had exit options which banks making loans did not have. The countries under attack thus had to respond rapidly and convincingly, employing in response an IMF-assisted combination of budgetary reforms, bank restructurings, and sharp currency devaluations. The crisis then moved on to Russia, where it triggered a government-bond default in August 1998, from there to Brazil, whom the IMF helped fend off a concerted attack in January 1999, and finally on to Argentina, whose currency board got destroyed in late 2001.

These two major currency crises had the desired effect of dramatically restructuring a large group of countries which until then had been politically cut off and economically marginalized from the capitalist system. The disintegration of Communism coincided with the failure of the post-colonial development consensus in favor of single-party states rapidly building up a government-directed industrial base of monopolies or local cartels behind protective walls (for instance, Mexico, Argentina, Brazil, India). ${ }^{17} \mathrm{We}$ were thus provided with a historic opening for bringing half of the world's population from one decade to the next into the orbit of capitalism. It took far-reaching reforms and dramatic exchange-rate adjustments, both enforced through the aforementioned crises, for many Latin American, Southern African, East European, and East Asian countries to turn into emerging-market economies (EMEs). Once those crises had opened up local economies in these four regions and rendered their assets accessible at much lower prices, the EMEs could rapidly become part of the global supply chain of the world's leading businesses and use their abundance of cheap labor pools to attract a significant portion of the world'smanufacturing capacity - the other side of the much-maligned 'outsourcing' in the West. Higher commodity prices in response to rapid increases in global demand further boosted the earnings capacity of EMEs during the 2000s. So they were able to launch aggressive export-led

17. For more on this post-colonial strategy of economic development in newly independent countries of Asia, Africa, and Latin America, known as import-substitution industrialization, see R. Prebisch (1959) - a key brain behind this state-centered and protectionist growth model. 
growth strategies and build large foreign-exchange reserves as buffers against future episodes of financial instability.

\subsection{The US dollar as world money}

For this growth pattern to sustain itself on such a wide scale for over 2 decades (1985-2007), someone else in the world economy had to absorb the trade surpluses of the emerging-market economies. Only one player was both willing and able to do that: the United States. Not only is its domestic economy four times larger than the next-largest (Japan, then China), but it has also possessed for over 6 decades now the 'exorbitant privilege' - a phrase coined aptly by French finance minister Valéry Giscard d'Estaing already in the 1960s - of being the only country in the world operating its economy without external constraint. The advantage of this position, put into place at the end of World War II with installation of the Bretton Woods system, stems from having to supply the rest of the world with dollars needed to pay for international transactions between countries or serve as foreign-exchange reserves. Such net outflows of dollars from their space of creation - the US banking system - to the rest of the world could only happen by running chronic US balance-of-payments deficits as a result of which more US dollars flowed out of the United States (to pay for foreign goods, services, or assets) than flowed into the United States (to get paid by foreigners buying US goods, services, or assets). Chronic US external deficits have thus in effect been automatically financed by the rest of the world accepting US dollars for payments or as reserves. To put it another way, the United States has the immense advantage of being able to borrow from the rest of the world in its own currency which it can create ex nihilo. Every other debtor country has to work for the money needed to service its foreign debt; the United States can just print it! ${ }^{18}$

During the first couple of postwar decades, the United States, running perennial trade surpluses until 1971, generated its external deficits through massive capital exports by its financial institutions, multinational corporations, military planners, and aid groups. Starting in the early 1980s, however, the US economy started running increasingly large trade deficits financed to a significant degree, but not fully, by capital imports. That trend reversal was triggered not least by the change in policy mix under 'Reaganomics,' whose combination of sky-high interest rates and large budget deficits (after massive tax cuts and military-spending increases in 1981) attracted large inflows of foreign capital, which in turn drove up the dollar and so reinforced US trade deficits. These deficits, turning Americans into the world's 'buyers of last resort,' were the necessary counterpart to the neo-mercantilist push for export-led growth by Germany, Japan, and the emerging-market economies. At the peak, in 2007, America's current-account deficit of 7.8 percent of its GDP absorbed threequarters of the surpluses from the rest of the world!

\subsection{The bubble economy}

America's ability to run large budget and trade deficits without any financing constraint has given its economic actors a license for excess spending, easily financed from the rest of the world. This systemic deficit-spending and debt-financing capacity, rooted in the

18. For a more extensive discussion of this major US advantage arising from its currency's pre-eminent international status, also known as global seigniorage, see Robert Guttmann (2004). 
world-money status of the US dollar, fueled the aforementioned financialization process into the direction of consecutive asset bubbles that gave the US economy additional stimulation over nearly a quarter of a century - the upswing phase of the long wave of finance-led capitalism (1982-2007). This particular Minskyan super-cycle, characterized by Ben Bernanke (2004) with premature optimism as the Great Moderation, was driven by financial markets rather than bank loans.

All three US asset bubbles were facilitated by key financial innovations which induced greater levels of debt within a newly formed shadow-banking system and so directed large amounts of capital to a certain asset class. ${ }^{19}$

- The first bubble, focusing on large US manufacturers left undervalued in the wake of brutal disinflation of the early 1980s, took off with the introduction of junk bonds by the investment bank Drexel. These speculative-grade and high-yielding bonds enabled a whole new generation of 'corporate raiders' to attack even the largest US firms deemed undervalued. Their hostile takeover bids were either successful, followed by radical restructuring to drive up the share price, or ended by paying off the attackers. The raiders were thus typically in a win-win situation. Soon any attack on a market leader would spur speculation as to who would be the next target in that sector and trigger further restructuring of the industry. The ensuing stock-market boom would last for nearly 5 years until the crash of October 1987. This bubble also put shareholder value maximization at the center of corporate governance, greatly expanded the number of firms able to issue bonds in lieu of bank loans, introduced private-equity funds (then known as 'leveraged buyouts'), and restored the stock market as a central locus of what was then about to become finance-led capitalism. The bursting of this bubble coincided with a significant domestic banking crisis (the so-called 'thrift crisis') to push the US economy into a fairly serious recession during 1990-1991.

- The second asset bubble emerged with the take-off of the internet in the mid 1990s when new e-commerce firms caught the world's attention. With NASDAQ's relaxation of listing requirements turning it into an attractive stock market for high-tech companies no longer required to show an established profit record before getting listed, venture capitalists and entrepreneurs could see imminent riches from successful initial public offerings (IPOs). The dot-com craze, which drove up the NASDAQ from 750 to over 5000 in just 5 years, reached a feverish pitch with the 'Y2K bug' sparking huge investments in new information technology. While that bubble burst in 2000 with the failure of many dot-com loss-makers and a spectacular collapse of NASDAQ (down to1800 in less than a year), it launched our leap into cyberspace which has spawned a whole new way of organizing our market economy (the 'New Economy'). At its center we now have a new generation of superlarge giants dominating the emerging online economy (Google, Amazon, Facebook, Apple, etc.).

- The third bubble, coming to the fore in the early 2000s as a historic housing boom, moved the locus of debt-financed speculation from financial assets to real assets and from corporations to households. Homeowners, over two-thirds of all US households, gained greater access to mortgages, including easier re-financings at lower rates and/or bigger balances, second mortgages, and home-equity

19. For a more detailed investigation of these three consecutive asset bubbles driving the upswing phase of the latest long wave marking finance-led capitalism, see Robert Guttmann (2009). 
loans which borrowers could spend for any use. As long as housing prices were going up, homeowners could borrow more against their homes as collateral. Continuous price hikes of real estate were assured by boosting housing demand through greater debt financing. The crucial innovation here were mortgagebacked securities, the bundling of mortgage loans for issues of bonds whose holders would receive most of the loan pool's income streams. Such securitization, which dramatically accelerated the turnover of funds for banks while also enabling them to transfer risks to bondholders, soon attracted a very large group of investors from all corners of the globe because of its comparatively high yields. Around 2004, banks introduced a variety of unorthodox mortgages, notably subprime mortgages targeting previously excluded demographic groups, to extend and deepen America's housing bubble. Making sure these riskier loans could be absorbed into the securitization pools while maintaining AAA ratings, the banks sought to spread out risks further. They securitized their mortgagebacked securities into collateralized debt obligations (CDOs), split CDOs into tranches carrying different levels of riskiness ('structured finance'), set up separate distribution systems for the different CDO tranches, and funded the structuredinvestment vehicles and hedge funds involved by letting those issue their own asset-backed commercial paper to access the world's money markets. Moreover, they tied the CDOs to credit-default swaps (CDS) - initially mostly for insurance purposes, but soon also to 'naked' CDS which allowed speculators to make bets on value fluctuations of portfolios without owning any of those ('synthetic finance'). This unprecedented funding machine, mobilizing over a trillion and a half dollars from across the globe in a matter of just 4 years to fuel America's housing boom, dramatically enhanced the borrowing capacity of US consumers treating their homes as ATMs. A majority of Americans thus had the means to engage in (largely debt-financed) excess spending which absorbed in turn the trade surpluses of neo-mercantilist rich nations (Germany, Japan) or emerging market economies (for example, Brazil, China) for many years.

\section{THE GREAT RECESSION (2007-201?)}

\subsection{The subprime bullet}

The bubble-driven growth pattern, connecting US excess spending and export-led growth elsewhere, could not last. In the wake of the Fed's 17 consecutive interest-rate hikes between July 2004 and August 2006, the frenzy surrounding US housing was bound to exhaust itself sooner or later. The bubble's peak in early 2007 coincided with a first wave of interest-rate resets on subprime mortgages (which typically had low 'teaser' rates for the first 2 years) leading suddenly to much higher debt-servicing charges for intrinsically vulnerable homeowners. No longer able to refinance those loans once housing prices stopped rising, a good many subprime borrowers went into default. These losses were soon large enough to eat through the higher-risk ('equity' and 'mezzanine') tranches of CDOs, thus spilling losses into the supposedly AAA super-tranches and putting those at risk. On 9 August 2007, BNP Paribas announced the closure of two funds impacted by the subprime crisis, explaining that their suspension had become necessary because they could no longer be properly valued. This announcement confirmed the worst fears of investors, namely that the loan pools underlying the multi-layered securitization infrastructure were no longer safe and that those layers could no longer be 
properly valued. The ensuing panic paralysed the intra-bank market and necessitated a massive liquidity injection from the ECB.

\section{2 'Bear runs' on banks}

At that point, the securitization infrastructure simply imploded, with many instruments no longer tradable and thus carrying major losses.

Worse, in the absence of reliable price formation, there was no way to estimate the timing and extent of losses. The ensuing uncertainty engulfed most of the planet, as it became clear how many non-US banks had financed this US housing bubble. While banks initially had some flexibility to declare whatever losses seemed most plausible to them and so make those estimations dependent on their ability to raise additional capital for loss absorption, that strategy could only buy so much time. Eight months into this fully fledged crisis, in March 2008 the collapse of Bear Stearns showed the Bush Administration willing to wipe out the shareholders of a failed bank in order to restitute in full its creditors. Not only did this unmistakable signal end whatever hope banks still had about getting shareholder support for recapitalization requests, it also made bank shares an unattractive investment.

From then on, we see a new type of panic run take root which sinks a string of major banks with devastating efficiency - Countrywide, IndyMac, Wachovia, Washington Mutual, Fannie Mae and Freddie Mac, etc. Whether prompted by welltimed rumors (often fueled by short sellers or CDS holders standing to gain from equity-price declines) or simply reflecting growing realization of the huge bank losses still pending, increased market concerns would now immediately translate into rising CDS premiums which soon became a widely watched indicator of market sentiments about the future of specific financial institutions. Any such spike in CDS premiums would spark a sell-off of bank shares and bonds which in turn would only aggravate the fragility of pressured banks. Once bank share prices had fallen below the critical threshold of $\$ 5 /$ share, at which point institutional investors had to divest from them, it was typically only a matter of days before the bank thus afflicted would fail.

\subsection{The Lehman shock}

By early September 2008, the US government faced many simultaneous brush fires it had to put out one way or another - notably the possible failure of Merrill Lynch, rumors of massive losses at the world's largest insurer AIG, and finally the muchanticipated insolvency of Lehman Brothers. Whether the Bush Administration lacked the powers to bail out Lehman (through acquisition by Barclays) or simply wanted to take a tougher stand on bank rescues, being concerned about the moral hazard arising from repeated bank rescues, it let Lehman go under. When that fateful decision triggered losses obliging the Reserve Primary Fund, the nation's first money-market mutual fund, to declare a net share value of less than the guaranteed one dollar per share ('breaking the buck'), all hell broke loose. The world's money market seized up, a full-blown credit crunch ensued, and the world economy went into a free-fall.

Luckily governments all over the world responded rapidly and decisively. Using the G20 governance structure, the US, EU, and many EMEs adopted a coordinated strategy whereby they kept their respective banking systems afloat with system-wide guarantees, introduced unorthodox monetary-policy measures centered around swaps and bond purchases to fight the debt-deflation spiral beyond the zero-bound limit, and 
pushed fiscal stimulus packages in support of aggregate demand. This three-pronged policy response soon halted the world economy's free-fall, with global GDP on the rise again in late 2009. Trade conflicts were largely kept in check, and a significant global push under the auspices of the G20 umbrella yielded even substantial financial regulatory reform - a new global framework defining capital requirements, leverage limits, and liquidity cushions for transnational banks known as Basel III, the landmark DoddFrank legislation in the US, and a new EU-wide set of banking and financial-market regulators empowered by a series of executive directives. ${ }^{20}$

Still, this is after all a structural crisis and as such is likely to persist while excessive debt levels have to be worked down, depleted savings restored, depressed asset prices rebound, and heightened uncertainty got used to. Deep wounds take a long time to heal! Moreover, there is always a second shoe that drops when it comes to structural crises: America's Panic of 1873 following the crashes in Germany and Austria 6 months earlier; the collapse of the gold standard in September 1931 following the stock-market collapse of October 1929; the dual currency-oil price shocks of 1973 following the end of Bretton Woods in August 1971. In this latest structural crisis, the global credit crunch triggered by the Lehman bankruptcy in September 2008 hit the eurozone as an asymmetric shock driving apart two divergent groups of countries while not allowing any of the proven adjustment mechanisms to restore a better intrazone balance between them. While the Europeans are desperately trying to work out their troubles, the US is still limping at a time when the super-fast expansion of the EMEs shows clear signs of slowing down. The divergent LUV-patterns of growth among these three make global policy coordination inherently more difficult at a time when such cooperation should be more important than ever.

\section{REFERENCES}

Aglietta, M. (1976 [1979]), Régulation et Crises du Capitalisme. Paris: Calmann-Lévy. (Translated as Theory of Capitalist Regulation: The US Experience. London: Verso, 1979.)

Aglietta, M. (1996), Financial Market Failures and Systemic Risk. Document de Travail \#96-01, Paris: CEPII.

Aglietta, M. (2001), Financial Instability and Monetary Regulation: Is Europe Well Protected from Systemic Risk? 3rd Conference of the St Gobain Centre for Economic Research on 'The Transformations of Finance in Europe,' Paris, 8-9 November. Accessed on 27 February 2012 at http://www.internationaleconomics.net/documents/fininstab.pdf.

Aglietta, M. and Moutot, P. (1993), Le Risque de Système et sa Prevention. Cahiers Economiques et Monétaires, 41: 22-25.

Aglietta, M. and Rebérioux, A. (2004 [2005]), Dérives du Capitalisme Financier. Paris: Albin Michel. (Translated as Corporate Governance Adrift: A Critique of Shareholder Value. Cheltenham, UK and Northampton, MA: Edward Elgar, 2005.)

Bernanke, B. (2004), The Great Moderation. Remarks at the Meetings of the Eastern Economics Association, 20 February, Washington, DC. Accessed on 17 March 2012 at http://www. federalreserve.gov/BOARDDOCS/SPEECHES/2004/20040220/default.htm.

Boyer, R. (1990), The Regulation School: A Critical Introduction. New York: Columbia University Press.

20. Elsewhere (Robert Guttmann 2012) I have tried to identify and critically evaluate the central themes of this multi-faceted global financial re-regulation effort, especially as it pertains to macro-prudential regulation of systemic risk, coping with the politically thorny 'too-big-to-fail' challenge of failing banks, new information-disclosure requirements, controlling shadow-banking systems, and strengthening financial markets. 
Boyer, R. (2000), Is a Finance-Led Growth Regime a Viable Alternative to Fordism? Economy and Society, 29(1): 111-145.

Boyer, R. (2004), The Future of Economic Growth: As New Becomes Old. Cheltenham, UK and Northampton, MA: Edward Elgar.

Boyer, R. and Mistral, J. (1978), Accumlation, Inflation et Crises. Paris: PUF.

Boyer, R. and Saillard, Y. (eds) (1995 [2002]), Théorie de la Regulation: L'État des Saviors. Paris: La Découverte. (Translated as Régulation Theory: The State of the Art. Routledge: London, 2002.)

Boyer, R., Dehove, M., and Plihon, D. (2004), Les Crises Financières. Report for the French Conseil d'Analyse Économique, Paris: La Documentation Française.

Brenner, R. and Glick, M. (1991), The Regulation Approach: Theory and History. New Left Review, 118: 45-119.

Burnside, C., Eichenbaum, M., and Rebelo, S. (2004), Government Guarantees and Self-Fulfilling Speculative Attacks. Journal of Economic Theory, 119(1): 31-63.

Chang, R. and Velasco, A. (2001), A Model of Currency Crises in Emerging Markets. Quarterly Journal of Economics, 116(2): 489-517.

Coriat, B. (1979), L'Atelier et le Chronomètre. Paris: Christian Bourgois.

Duménil, G. and Lévy. D. (1993), Why Does Profitability Matter? Profitability and Stability in the U.S. Economy since the 1950s. Review of Radical Political Economy, 25(1): 27-61.

Duménil, G. and Lévy, D. (2002), The Profit Rate: Where and How Much did it Fall? Did it Recover? (USA 1948-2000). Review of Radical Political Economy, 34(3): 437-461.

Epstein, G. (ed.) (2006), Financialization and the World Economy. Cheltenham, UK and Northampton, MA: Edward Elgar.

Frydl, E. (1979), The Debate over Regulating the Eurocurrency Markets. Federal Reserve Bank of New York Quarterly Review, 4: 11-30.

Frydl, E. (1982), The Eurodollar Conundrum. Federal Reserve Bank of New York Quarterly Review, 2: 11-19.

Guttmann, R. (1997), Reforming Money and Finance: Toward a New Monetary Regime. Armonk, NY: M.E. Sharpe.

Guttmann, R. (2004), How Credit-Money Shapes the Economy: The United States in a Global System. Armonk, NY: M.E. Sharpe.

Guttmann, R. (2008), A Primer on Finance-Led Capitalism and its Crisis. Revue de la Régulation, 3/4, December. Accessed on 16 March 2011 at http://regulation.revues.org/document5843. html.

Guttmann, R. (2009), Asset Bubbles, Debt Deflation, and Global Imbalances. International Journal of Political Economy, 38(2): 46-69.

Guttmann, R. (2012), Financial Regulation: Why and How? Veblen Institute of Economic Reforms. Accessed on 19 September 2013 at http://www.veblen-institute.org/FinancialRegulation-Why-and- How?lang=en.

Hayek, F. (1933 [1975]), Monetary Theory and the Trade Cycle. New York: Augustus M. Kelley. Hayek, F. (1935 [1967]), Prices and Production, 2nd edn. New York: Augustus M. Kelley.

Hein, E. (2012), The Macroeconomics of Finance-dominated Capitalism - and its Crisis. Cheltenham, UK and Northampton, MA: Edward Elgar.

Jessop, B. (ed.) (2001), Regulation Theory and the Crisis of Capitalism. Cheltenham, UK and Northampton, MA: Edward Elgar.

Kalecki, M. (1935), A Macrodynamic Theory of Business Cycles. Econometrica, 3(2): 327-344.

Kalecki, M. (1937), A Theory of the Business Cycle. Review of Economic Studies, 4(1): 77-97.

Kalecki, M. (1942), A Theory of Profits. Economic Journal, 52(206/207): 258-267.

Kane, E. (1981), Accelerating Inflation, Technological Innovation, and the Decreasing Effectiveness of Banking Regulations. Journal of Finance, 36(2): 355-367.

Kindleberger, C. (1978), Manias, Panics, and Crashes. New York: Basic Books.

Kondratiev, N. (1925 [1984]), The Major Economic Cycles (in Russian), Moscow. (Translated as The Long Wave Cycle, New York: Richardson \& Snyder, 1984.)

Kondratiev, N. (1926 [1936]), Die langen Wellen der Konjunktur. Archiv für Sozialwissenschaft und Sozialpolitik, 56: 573-609. (Translated as The Long Waves in Economic Life. Review of Economic Statistics, 17(6): 105-115, 1936.) 
Krippner, G. (2005), The Financialization of the US Economy. Socio-Economic Review, 3(2): 173-208.

Krugman, P. (1979), A model of balance-of-payments crises. Journal of Money, Credit, and Banking, 11(2): 311-325.

Lipietz, A. (1979), Crise et Inflation, Pourquoi? Paris: Maspero.

Mandel, E. (1970), Marxist Economic Theory. New York: Monthly Review Press.

Mandel, E. (1980), Long Waves of Capitalist Development: A Marxist Interpretation. Cambridge, UK: Cambridge University Press.

Marx, K. (1867 [1992]), Capital, Vol. I. London: Penguin Classics.

Marx, K. (1894 [1959]), Capital, Vol. III. New York: International Publishers.

Mensch, G. (1979), Stalemate in Technology: Innovations Overcome the Depression. Cambridge, MA: Ballinger.

Minsky, H. (1964), Longer Waves in Financial Relations: Financial Factors in More Severe Depressions. American Economic Review, 54(1): 324-335.

Minsky, H. (1980), Capitalist Financial Processes and the Instability of Capitalism. Journal of Economic Issues, 54(2): 505-523.

Minsky, H. (1982), Can 'It' Happen Again? Essays on Instability and Finance. Armonk, NY: M.E. Sharpe.

Minsky, H. (1986), Stabilizing an Unstable Economy. New York: McGraw-Hill.

Minsky, H. (1992), The Financial Instability Hypothesis. Working Paper No 74, Annandale-onHudson, NY: Levy Institute.

Mises, L. von (1912 [1953]), Theory of Money and Credit. New Haven, CT: Yale University Press.

Obstfeld, M. (1986), Rational and Self-Fulfilling Balance-of-Payments Crises. American Economic Review, 76(1): 72-81.

Orhangazi, O. (2008), Financialisation and Capital Accumulation in the Non-Financial Corporate Sector. Cambridge Journal of Economics, 32(6): 863-886.

Palley, T. (2009), A Theory of Minsky Super-Cycles and Financial Crises. IMK Working Papers No 05-2009, Düsseldorf, Germany: Hans Boeckler Foundation.

Prebisch, R. (1959), Commercial Policy in Underdeveloped Countries. American Economic Review, 49(1): 251-273.

Reinhardt, C. and Rogoff, K. (2009), This Time is Different: Eight Centuries of Financial Folly. Princeton, NJ: Princeton University Press.

Schumpeter, J. (1939), Business Cycles. New York and London: McGraw-Hill.

Schumpeter, J. (1942), Capitalism, Socialism and Democracy. London: Routledge.

Setterfield, M. (2011), Anticipations of the Crisis: On the Similarities between Post-Keynesian Economics and Regulation Theory. Revue de la Régulation, 10, June. Accessed on 4 November 2012 at http://regulation.revues.org/!9366?\&id=9366\#text.

Silverberg, G. (2003), Long Waves: Conceptual, Empirical and Modelling Issues. Research Memoranda, No 15. Maastricht, The Netherlands: Maastricht Economic Research Institute on Innovation and Technology. Accessed on 24 February 2012 at http://ideas.repec.org/p/ dgr/umamer/2003015.html.

Stockhammer, E. (2008), Some Stylized Facts on the Finance-Dominated Accumulation Regime. Competition and Change, 12(2): 184-202.

Wray, R. (2009), The Rise and Fall of Money Manager Capitalism: A Minskian Perspective. Cambridge Journal of Economics, 33(4): 807-828.

Wray, R. (2011), Minsky's Money Manager Capitalism and the Global Financial Crisis. Working Paper No 661, Annandale-on-Hudson, NY: Levy Institute. 